\title{
AN ANALYSIS OF THE DETERMINANTS OF FOREIGN DIRECT INVESTMENT IN TURKEY: THE ROLE OF THE INSTITUTIONAL CONTEXT ${ }^{1}$
}

\author{
Devrim Dumludag \\ University of Groningen P.O. Box 72, 9700 AB Groningen, Netherlands Marmara University \\ Göztepe Campus 34722/Kadiköy - Istanbul, Turkey \\ E-mail:dumludag@marmara.edu.tr
}

Received 20 November 2007; accepted 3 December 2008

\begin{abstract}
This paper tries to empirically verify the argument that institutional factors such as enforcement mechanisms, political and economic stability, stable and reliable, transparent legal and regulatory framework and corruption are critical in explaining the behaviour of the foreign direct investment inflows in Turkey. The main objective of the study is to ascertain the nature of the obstacles and impediments to the greater flow of foreign direct investments into Turkish economy for the recent period by focusing on the results of a questionnaire applied to the executives of 52 multinational corporations operating in Turkey in 2006.
\end{abstract}

Keywords: Foreign Direct Investment, Turkey, institutions

\section{Introduction}

Since 1980, the Foreign Direct Investment (FDI) inflows to developing countries have been substantially increasing and compared to other capital flows, have remained the largest component of net resource flows to developing countries (UNCTAD 2006a). In these countries, governments believe that FDI will help economic development and they try to attract FDI through policies and investment incentives designed to increase investor interest in an attempt to benefit from the potential economic development. Hence, with the liberalization of many developing economies, FDI has become a crucial medium through which developing economies become unified on a global basis.

On the other hand, despite several efforts of governments, Turkey has never been able to attract the substantial FDI inflows that would be expected from a nation with a strategic location between Europe, the Middle East and Central Asia².

In this paper, I conducted a questionnaire survey to explore the mechanisms linking macroeconomic vari- ables and political institutions to FDI flows, and interviewed representatives of Multinational Corporations (MNCs) operating in Turkey in order to understand the reasons of low level of FDI flows into the country.

\section{FDI Performance of Turkey from a Comparative Perspective}

Turkish FDI levels have stagnated during the 1990s while total FDI worldwide increased by a factor of 12. This lack of interest by multinational companies becomes even clearer when FDI inflows are adjusted to the size of the economy. Over the last decade, the average FDI inflows to middle-income countries in Europe were 1.1 percent of GDP compared to less than 0.5 percent in Turkey. As shown in the following figure, this disparity is considerably greater when Turkey is compared to the countries investors considered to be its main regional competitors: Hungary, the Czech Republic, and Poland.

Fig. 1 reveals the inward FDI stock levels of selected emerging economies as a percentage of GDP. Com- 
paring Turkey with other emerging economies such as Brazil, Mexico, Hungary, Czech Republic, and Poland, it can be argued that the inward FDI performance of Turkey is ineffective. The level of FDI stock in Turkey remained stagnant at approximately 10 percent during the 1990s, fluctuated after 2000 and reached approximately 12 percent in 2005. Whereas inward FDI stock of all other countries increased significantly. Hungary and the Czech Republic are the most successful countries at attracting increasing inward FDI stock. The transition economies of Central and Eastern Europe, although entering the competition in the beginning of the 1990s, attracted more FDI in comparison to Turkey in the period.

Another way to view Turkey's relative FDI performance as a host country is in terms of two indices developed by UNCTAD: The FDI Performance Index and the FDI Potential Index.

Table 1. The Inward FDI Performance Index Rankings

\begin{tabular}{lcccc}
\hline Selected & $2003-$ & $2002-$ & $2001-$ & $2000-$ \\
Countries & 2005 & 2004 & 2003 & 2002 \\
\hline Czech Republic & 32 & 25 & 13 & 10 \\
\hline Hungary & 40 & 46 & 33 & 27 \\
\hline Poland & 57 & 75 & 68 & 56 \\
\hline Mexico & 75 & 79 & 61 & 64 \\
\hline Brazil & 82 & 62 & 46 & 37 \\
\hline Argentina & 83 & 82 & 82 & 85 \\
\hline Turkey & 95 & 111 & 110 & 109 \\
\hline
\end{tabular}

Source: UNCTAD 2006a.
The Inward FDI Performance Index ranks countries by the FDI they receive relative to their economic size. It is the ratio of a country's share in global FDI inflows to its share in global GDP (Table 1$)^{3}$. The Index is shown for three-year periods to offset annual fluctuations in the data and covers 141 economies for as much of the period as the data permit; however, some economies in transition could not be ranked in the early years for lack of data or because they did not exist as separate countries $^{4}$.

According to the inward performance index, Turkey ranks 95th with a score of 0.917 . This low score indicates that Turkey receives less FDI than its relative economic size.

A more complex index, the Inward FDI Potential Index, captures several factors (apart from market size) expected to affect an economy's attractiveness to foreign investors. It is an average of the values of 12 variables ${ }^{5}$ :

Table 2. The Inward FDI Potential Index Rankings

\begin{tabular}{lcccc}
\hline $\begin{array}{l}\text { Selected } \\
\text { Countries }\end{array}$ & $\begin{array}{c}2003- \\
2005\end{array}$ & $\begin{array}{c}2002- \\
2004\end{array}$ & $\begin{array}{c}2001- \\
2003\end{array}$ & $\begin{array}{c}2000- \\
2002\end{array}$ \\
\hline Hungary & 37 & 40 & 41 & 43 \\
\hline Czech Republic & 39 & 39 & 42 & 42 \\
\hline Poland & 43 & 43 & 44 & 46 \\
\hline Mexico & 53 & 51 & 50 & 49 \\
\hline Argentina & 67 & 66 & 77 & 52 \\
\hline Turkey & 68 & 72 & 72 & 74 \\
\hline Brazil & 71 & 70 & 68 & 73 \\
\hline
\end{tabular}

Source: UNCTAD 2006a.

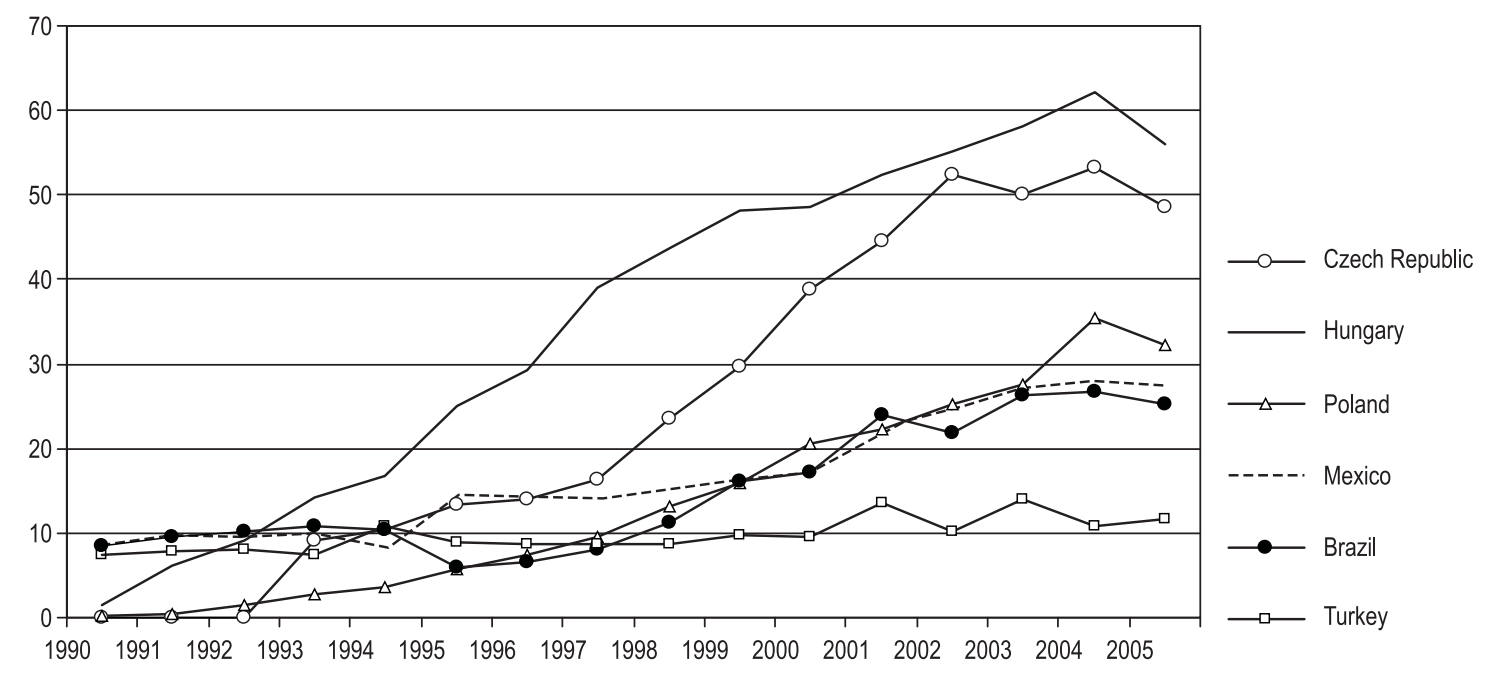

Fig. 1. Inward FDI Stock as percentage of GDP in Selected Emerging Economies Source: UNCTAD 2006b 
Table 2 demonstrates that, Turkey has a better position than Inward FDI performance index, however, still standing behind other emerging markets. Central and East European countries are more successful than selected Latin American countries. The strength in education and infrastructure in these countries makes them attractive, especially for firms motivated by vertical strategy.

According to the matrix of the FDI potential and FDI performances of the countries, Turkey takes place within the list of countries that have high FDI potential but low FDI performance ${ }^{6}$. In order to understand the reasons why countries attract different amounts of FDI, in specific, why Turkey receives FDI flows below its potential, a brief overview of the existing literature on the determinants of FDI is of the essence.

\section{The Determinants of Foreign Direct Investment and the role of Institutions}

\subsection{Core Theories of FDI}

The motives for investing abroad either by establishing a new corporation or investing in established firms have received remarkable attention from scholars ${ }^{7}$. Their main concern is answering the question: What explains patterns of FDI flows across the globe?

The literature on determinants of FDI is very new. The early writings on FDI go back only to the 1950s. Until the 1960s, except for a few works by political economists, there was no systematic explanation of, model of or theory on FDI activities. Stephen Hymer (1976) made the first theoretical approach ${ }^{8}$. He was one of the first scholars to separate FDI from portfolio investment and initiated a new literature on the determinants of FDI. Through 1960 and 1970 new theories of FDI were introduced. Vernon (1966) used the product life cycle approach, which is based on the existence of market imperfections across nations, to develop a theory of foreign direct investment. Later, it was argued that monopolistic advantages, which are created by both advertising and research and development investments, characterize not just specific firms but rather firms within oligopolistic industries. Knickerbocker (1973) showed evidence that the timing of U.S. MNCs' FDI is largely determined by their oligopolistic reaction "follow the leader" theory to competitors' investment.

While industrial organization models were the dominant line in studying FDI until the 1970s, a new theory, called "internationalization theory," was proposed to explain how firms are involved in international op- erations and make resource commitments to foreign markets. The term "internationalization" is used to describe an evolutionary process in which the firm gradually increases its international involvement.

In the 1970s, Dunning's eclectic paradigm dominated the literature. Dunning introduced the concept of "OLI" as a theoretical framework to analyze the determinants of FDI. This framework considers FDI as determined by Ownership, Location and Internalization advantages of firms investing abroad (Dunning 1970). The OLI paradigm has remained the center of FDI theory and other scholars have expanded on this framework.

More recently, the motives of FDI have been examined in two categories. In this view a firm realizes the investment to better serve the local market or to get lower-cost inputs, or both. In other words, FDI can be divided into "horizontal" or "market-seeking" FDI, and "vertical" or "efficiency-seeking" FDI.

The first involves building plants in a host country to supply the local market. This approach is done to reduce the costs that arise from supplying the market through exporting, in which case, market size and high tariffs play a large role in determining profitability. The latter category of vertical FDI is production cost-minimizing, where firms seek to produce in lower cost locations or seek inexpensive inputs in order to export their product. Inexpensive inputs include natural resources, raw materials, or low-cost inputs such as labour. In other words, differentiation between the two is that market-seeking FDI aims at penetrating the local markets of the host country, whereas efficiencyseeking FDI is interested in creating new sources of competitiveness for firms.

Finally, Asset-Seeking FDI is the most recent motive for FDI to be identified. It refers to a strategy that aims to access and exploit technological assets in overseas countries. Developed countries are the main recipients of R\&D investment, but countries such as Hungary, Czech Republic, India and Brazil are also attracting more and more Research and Development projects. Asset-seeking MNCs focus on the skilled labour availability, research institutes, large supply of graduate labour, created assets including innovative capacity, technological adoption, and technical skills when choosing an investing location (Michalet 1997: 12-15). FDI driving forces and outcomes for host economies have been thoroughly analyzed in recent scientific literature (Ginevičius and Tvaronavičienė 2003, 2004; Tvaronavičienè and Degutis 2007; Tvaronavičienè and Grybaite 2007; Tvaronavičienė et al. 2008; Degutis and Tvaronavičienė 2006). 


\subsection{The Role of Institutions}

As seen above, studies of FDI flows at the firm level, in common, emphasize that firms as profit maximizing agents are motivated by exploiting their own advantages abroad, such as access to patented technology, specific management or marketing skills or ownership of brand names. This view is firm-level centered, yet, in these studies; the role of social, political and economic institutions has rarely been treated.

On the other hand, since the 1990s, in the international literature, the number of studies mentioning the importance of institutions determining economic growth and FDI has increased significantly. Especially in the economic growth literature, a number of scholars such as Knack and Keefer (1995: 207-227), Mauro (1995: 681-712), Hall and Jones (1999), Acemoglu et al. $(2002,2005)$ have emphasized that political, institutional and legal environment of a country, to a great extent, determine the economic performance. Institutions lead to a fall in both transaction and information costs by reducing uncertainty and establishing a therefore stable structure to facilitate interactions, define and enforce property rights; and determine the degree of competition by defining the terms of market entry (North 1990; Coase 1960). Hence, the stronger the political, economic and social institutions are, the higher the economic growth rates realized will be.

Institutions can be economic, political or social in nature. Economic institutions determine the "economic rules of the game"-in particular, the degree of property rights enforcement, the set of contracts that can be written and enforced, and some of the rules and regulations that determine the economic opportunities open to agents (individual property rights, commercial law, contract law, patent law, the type of credit arrangements, etc. $)^{9}$.

The institutional framework has three components: formal rules, informal rules, and enforcement mechanisms. Formal rules are the written rules of a society. Laws governing contracts, crime, political systems, product information, the imposition of tariffs or quotas, the regulation of banks, and so on are all formal institutions (North 1990: 36-61). Formal rules can be created by firms as well as governments.

Informal rules are the unwritten rules of a society. These include culture, norms of behaviour, codes of conduct, and so on. Citizens of a country grow up learning all kinds of unwritten norms and attitudes and informal rules differ across nations (for example, meal times are often set by custom).
The third component of the institutional framework is enforcement. Institutions often are ineffective if they are not enforced. For example, a nation can have antitrust laws that prevent firms from becoming monopolies, but if the government does not enforce such laws, businesses may act as if the antitrust law did not exist. Some institutions are self-enforcing (for example, driving on the right side of the road when no police are in sight). Enforcement is not an all-or-nothing phenomenon. Countries may enforce laws strongly, marginally, or not at all. Enforcement is an integral part of a nation's institutional framework and may be the single most important element in explaining differences in economic performance (North 1990: 54-61).

\subsection{FDI and institutions literature review}

In the international literature, scholars studying the relationship between institutions and FDI face several difficulties for the reason that, institutional variables are not readily available. To meet the needs for an in-depth and exhaustively researched analysis of the non-economic variables such as potential risks to international business operations, several organizations created statistical models to calculate risks and backed it up with analyses that explain the numbers and examine what the numbers do not show. The result is a comprehensive system that enables various types of risk to be measured and compared between countries.

The data measuring the quality of institutional variables are produced by independent private firms who provide consulting services to international investors such as the PRS Group publishing the International Country Risk Guide (ICRG), the Freedom House (FH), or the Transparency International (TI). To a certain extent, these indices provide very similar information on various aspects of institutions. However, some should pay attention to the facts that first indices can be considered to be subjective and more important, they measure the perceptions of governance quality rather than its actual quality.

In the literature there are several empirical studies mentioning the importance of institutional variables by applying econometric models or questionnaire surveys. Empirical research on the impact of host country institutions on FDI has demonstrated that the general institutional, social and legal framework influences FDI.

Wei (1997) states that corruption within the political system is a threat to foreign investment by distorting the economic and financial environment, reducing the efficiency of the government and business by enabling people to assume positions of power through patronage 
rather than ability, and introducing inherent instability into the political process. Mauro (1997) uses the Business International (BI) indices to argue that corruption does in fact hurt growth and investment. The findings of Habib and Zurawicki (2001) support the argument that high level of corruption deters FDI.

A number of studies mention that lack of political and economic stability, unclear regulatory frameworks, an inexperienced bureaucracy, an underdeveloped court system deter more FDI inflows to host economies. Wheeler and Mody (1992) examine American firms investing abroad and write that political risk factors, the functioning of the bureaucracy, corruption and judicial system have strong impact on these firms and they emphasize that these facts had strong negative impact on MNCs operating abroad.

Gastanaga et al. (1998) examined the relationship between political variables and FDI and found that high enforcement mechanisms, low corruption levels affect FDI positively. Oxley (1999) and Smarzynska (1999) found that weak property rights inhibit FDI inflows.

In his comprehensive study, Jensen (2006) states that the overall effect of democratic institutions is positive and democracies should be associated with higher inflows of FDI. Li and Resnick (2003) argue that incremental improvements in property rights protection induce a more attractive environment for foreign direct investors.

In his doctorate dissertation, Dumludag (2007) applies panel data regressions (factor analysis) including 67 developing countries for the period 1984-2005. The results of the dissertation make a real contribution to the empirical literature by validating the role of a large set of institutional variables (such as democratic accountability, corruption, investment profile, government stability, political rights, and civil liberties) on foreign direct investment flows. Dumludag and Sukruoglu (2007) find the same results when they applied panel data regressions for 22 emerging countries.

The second group of cross-country analyses including more recent data emphasizes the importance of human capital as a significant determinant of FDI. Noorbakhsh et al. (2001) using a dataset that covers the 1980s to the mid-1990s, empirically tested the hypothesis that the level of human capital in host countries may affect the geographical distribution of FDI. These empirical findings are: (a) human capital is a statistically significant determinant of FDI inflows; (b) human capital is one of the most important determinants; and (c) its importance has become increasingly greater through time. Nunnenkamp and Spatz (2002) report that efforts to provide better education and training would enhance the economic growth effects of FDI in developing countries.

\section{The Turkish case and the survey}

This paper tries to empirically verify the argument that in institutional factors such as enforcement mechanisms, political and economic stability, civil and political rights and corruption are also critical in explaining the behaviour of the foreign direct investment inflows in case of the Turkish economy.

There is a growing literature on FDI inflows to Turkey. While some of them focus on the macroeconomic or microeconomic variables as determinants, some conduct surveys and list the results by using macro data, industry data, and firm level data.

In the 1960s and 1970s, Selik (1961), Esiner (1966), Oksay (1967), Bulutoglu (1970), in their descriptive studies, explained regulations concerning FDI and every legal and procedural step to be taken by the potential investor in Turkey. However, the studies lack guidelines on how to improve the investment climate and how to encourage a greater inflow of the foreign capital urgently needed for the development of Turkey.

Tuncer (1968) represents the most serious and scientific research undertaken in Turkey on the subject of FDI in the 1960s. It is comprehensive and objective and it seems to be the result of extensive documentary research. The study concludes that the place of foreign investment in the total private investment in Turkey is not important and its effect on employment is not significant because of its concentration in capital intensive operations.

In the 1970s the number of studies using questionnaire surveys increased. Ashkin (1972) used techniques such as documentary research, questionnaire surveys, and personal interviews. He shows the dimensions of foreign firms containing foreign capital in Turkey, the attitudes of these firms towards the Turkish economy, the investment and financial climate, government applications and public opinion. Later, Șahin (1975), arguing that the statistical data were unreliable spent his time searching for reliable data. He also used the results of questionnaires (79 of 112 firms containing foreign capital). According to his questionnaire results, he confirms that FDI inflow in Turkey is below the level expected in the period examined and then offers suggestions in order to attract more FDI.

In 1979 Uras, who is a former DPT expert, wrote a book titled Türkiye'de Yabancı Sermaye Yatırımları (Foreign Direct Investment in Turkey). During his research, he administered a questionnaire to the staff of a number of firms containing foreign capital. Erdilek (1982) investigated the microeconomic causes 
and effects of FDI in Turkish manufacturing. Erdilek collected data from individual firms directly (46 of 83 firms) through extensive interviews and a questionnaire designed for the study. His work shows the contribution of FDI into manufacturing sector, clarifies the low level of FDI inflow into Turkey, and offers policy suggestions. Also Karluk (1982) discusses the dimensions of foreign firms containing foreign capital in Turkey. In addition, Karluk looks at other country cases and furnishes examples. In Turkey he administered questionnaires to 51 of 146 firms. Like other researchers, he found that FDI inflow was insignificant. Erdilek (1986) evaluated the effects of the change in the attitude of governments' toward FDI for the post1980 period.

In the 1990s without creating a theoretical framework, Erden (1996) presents the questionnaire results acquired from 217 of 2.358 firms. Erden evaluates the export, employment, and tax revenue contributions of FDI firms and reveals the attitudes of these firms toward the Turkish economic climate and government policies. Tatoğlu (1998) in his doctorate dissertation provides an empirical analysis of the core dimensions of FDI activity based on primary data collected from Western multinationals engaged in either whollyowned subsidiaries or joint ventures and from local Turkish firms which are partners in joint ventures in Turkey.

In a recent study, Foreign Investor Advisory Service of the World Bank (FIAS) conducted reports, mentioning the importance of institutions without building a theoretical framework. FIAS of the World Bank Group was asked in September 2000 to study the FDI environment and make recommendations for its improvement, as part of the World Bank Group's 2001-2003 Country Assistance Strategy for Turkey, which stressed the importance of FDI repeatedly and underscored the role of FIAS in improving Turkey's FDI environment.

FIAS, with the support of the Turkish government and with cooperation of the private sector, prepared two studies: A Diagnostic Study of the Direct Foreign Investment Environment in Turkey in February 2001, and: Turkey: Administrative Barriers to Investment in June 2001. The reports pointed administrative barriers, political and economic stability, slow and partial judicial system as an impediment to new investments and suggested workshops and establishment of study groups focusing on the issues such as company registration, sectoral licensing, land access and site development, taxation and incentives, intellectual property rights, investment legislation and investment promotion.
While there are some other studies dealing with FDI in Turkey in the form of articles, books or chapters in books, the studies mentioned here are the best known and most comprehensive ones. Their common elements are that the authors administered questionnaires to FDI firms, applied econometric models, they relied on primary sources, in some cases generated their own statistical data by collecting sources, and they examined the contribution of FDI firms to Turkish economy, the reasons for the low level of FDI inflow and finally, most of them offer similar suggestions to increase the inflow of FDI.

On the other hand, not all of them built strong theoretical frameworks from an institutional perspective or conducted complete surveys of theoretical studies. While some of them focus on the macroeconomic or microeconomic variables as determinants, some conduct surveys and list the results without coherent theoretical framework.

\subsection{Questionnaire Survey}

In my empirical analysis, I engaged in substantial fieldwork in 2006. I conducted a questionnaire survey to explore the mechanisms linking macroeconomic variables and political institutions to FDI flows, and interviewed representatives of Multinational Corporations (MNCs) operating in Turkey. In these interviews I asked both open-ended and closed-ended questions regarding the factors that were important in multinationals selecting investment locations, and I followed up these questions with specific questions on how they evaluated the importance of specific policies and institutions ${ }^{10}$. Also, I had the opportunity to conduct interviews with some of the representatives of nongovernmental organizations.

The questionnaire not only examines the impact of institutional variables on FDI, but also the effect of horizontal and vertical strategies is examined. The case study of how institutional, horizontal and vertical variables affect FDI in Turkey is the result of field work of twenty weeks. The questionnaires were sent in October 2006 and the receiving of the results was completed in February 2007. The questions examine the period between 2001 and 2006. The answers of the questions are converted to numeric values (from very low: 1 to very high: 5 , very unimportant to very important 1:5). The questionnaire survey was drafted in such a manner as to follow a systematic comparison of the investment environment surveys of the World Bank and UNCTAD.

The MNCs firms are at the top of 500 big (according to initial capital stock) MNCs in located on the 
website of the Undersecretariat of Treasury in Turkey. All participants in the study were guaranteed complete confidentiality in their responses. Hence, in-keeping with this confidentiality clause, the data presented in this paper is based upon the summary statistics drawn from the database of survey respondents.

The questionnaires were sent by mail to 300 executives of MNCs. However, 52 executives returned their surveys. 18 firms replied that they were either unable or unwilling to participate in the study, most stating company policy and/or confidentiality issues as reasons for their non-participation. A further 40 questionnaire packets were returned unopened and given the fact that these firms had recently relocated.

In the survey, 40 of 52 respondents were general managers; five of them were finance managers, four of them marketing managers and three of them assistant general managers.

The sectoral distribution of responding firms is demonstrated in Fig. 2.

Thirty-seven percent of the firms belong to financial intermediation; manufacturing is the second largest sector with a share of 27 percent to which the respondents belong. The transport, storage and communications sector is the third largest sector with 12 percent. Wholesale and Retail Trade has eight percent, whereas, construction sector has a share of four percent. Other sectors, including agriculture, electricity, real estate, wholesale and retail have 12 percent in total.

On the other hand, the sectoral distribution of MNCs operating in Turkey by 2006 can be seen in Fig. 3 . According to Fig. 3, 40 percent of the MNCs in Turkey operate in the financial intermediation sector. The transport, storage and communications sector has a share of 38 percent, very close to financial intermediation. Third largest sector MNCs belong to is manufacturing with a share of eleven percent. The wholesale and retail trade sector has a share of five percent.

The sectoral distribution of respondents firms is similar to the sectoral distribution of total MNCs in Turkey, except that the second largest sector is manufacturing with 27 percent in the questionnaire survey, whereas it is the third largest sector with a share of 11 percent. On the other hand, the transport, storage and communications sector is the second largest sector with 38 percent in Turkey, it has a share of 12 percent in the survey.

Executives of MNCs agree that Turkey's one of the strongest attractions is its large domestic market. The consensus on this is very strong, and is seen in every survey ${ }^{11}$.

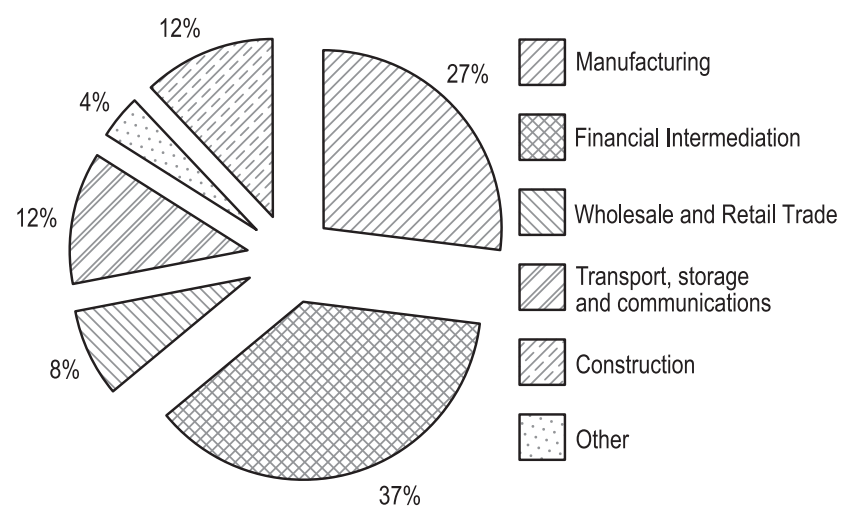

Fig. 2. Sectoral Distribution of MNCs - Survey Results - 2006. Other: agriculture, electricity, real estate, wholesale and retail trade

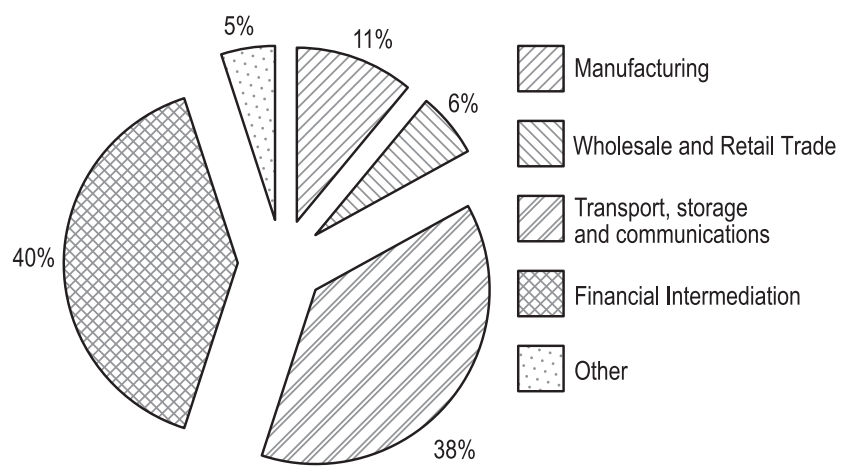

Fig. 3. Sectoral Distribution of FDI in Turkey. Other: Agriculture, construction, electricity, gas and water supply, health and social work, hotels and restaurants, real estate

Table 3 demonstrates that growth of the market with a mean of 4.29 is the initial motive for foreign investors operating in Turkey. The size of the market with a mean of 3.69 and penetration into a new market with a mean of 3.33 show that the Turkish economy is attractive for foreign investors regarding horizontal strategy. To watch or forestall a competitor's motive with the lowest mean of 2.38 implies that foreign investors pay attention to market size economy more than just forestalling a competitor's action.

High mean scores of horizontal strategy (higher than vertical strategy) reveal that the most important motives are the market size related indicators. The executives, during the interviews, mentioned the importance of the growth of the market and added that thanks to stabilization policies, they expect continuous high growth rates.

From Table 4 it could be suggested that although horizontal strategy is a priority for foreign investors, vertical strategy also plays an important role for them. Turkey scores higher in availability of skilled labour than its East European competitors. In 2000 Turkey 
ranked eighth in the world in terms of the availability of competent senior managers (plus, ranked third in the world for the average number of hours worked per year), well ahead of Hungary $31^{\text {st }}$, Poland $40^{\text {th }}$ and the Czech Republic $46^{\text {th }} 12$.

Table 3. Motives for Foreign Direct Investment in Turkey

\begin{tabular}{lcccc}
\hline $\begin{array}{l}\text { Horizontal } \\
\begin{array}{l}\text { Strategy } \\
\text { Indicators }\end{array}\end{array}$ & $\begin{array}{l}\text { Number of } \\
\text { Responses }\end{array}$ & Mod & Mean & $\begin{array}{c}\text { Standard } \\
\text { Deviation }\end{array}$ \\
\hline $\begin{array}{l}\text { Growth of the } \\
\text { market }\end{array}$ & 51 & 5 & 4.29 & 1.183 \\
\hline $\begin{array}{l}\text { Size of the } \\
\text { market }\end{array}$ & 52 & 4 & 3.69 & 0.781 \\
\hline $\begin{array}{l}\text { Penetration into } \\
\text { a new market }\end{array}$ & 52 & 3 & 3.33 & 1.167 \\
\hline $\begin{array}{l}\text { Anticipation of } \\
\text { relatively high } \\
\text { profits }\end{array}$ & 52 & 2 & 3.29 & 1.21 \\
\hline $\begin{array}{l}\text { To watch or } \\
\text { forestall a } \\
\text { competitor's } \\
\text { motive }\end{array}$ & & & & \\
\hline
\end{tabular}

Table 4. Motives for Foreign Direct Investment in Turkey

\begin{tabular}{|c|c|c|c|c|}
\hline $\begin{array}{l}\text { Resource, } \\
\text { Efficiency, } \\
\text { Asset-Seeking } \\
\text { Strategy }\end{array}$ & $\begin{array}{l}\text { Number of } \\
\text { Responses }\end{array}$ & Mod & Mean & $\begin{array}{c}\text { Standard } \\
\text { Deviation }\end{array}$ \\
\hline Cheap labour & 51 & 3 & 3.37 & 1.183 \\
\hline $\begin{array}{l}\text { Export base for } \\
\text { neighbouring } \\
\text { markets }\end{array}$ & 49 & 4 & 3.24 & 1.234 \\
\hline $\begin{array}{l}\text { Availability of } \\
\text { skilled labour }\end{array}$ & 51 & 4 & 3.22 & 0.808 \\
\hline $\begin{array}{l}\text { Availability } \\
\text { of industrial } \\
\text { infrastructure }\end{array}$ & 52 & 3 & 3.12 & 1.132 \\
\hline $\begin{array}{l}\text { Cost of } \\
\text { transportation }\end{array}$ & 48 & 3 & 3.08 & 0.895 \\
\hline $\begin{array}{l}\text { Innovative } \\
\text { capacity, } \\
\text { technological } \\
\text { skills, } \\
\text { technological } \\
\text { adoption }\end{array}$ & 47 & 4 & 3.06 & 1.009 \\
\hline $\begin{array}{l}\text { Gaining access } \\
\text { to raw materials }\end{array}$ & 50 & 3 & 2.78 & 1.25 \\
\hline
\end{tabular}

In Turkey not only cheap labour for foreign investors is appropriate (with a mean 3.37), but the availability of skilled labour is also important with a mean score of 3.22. Some should take into account that most of the respondents belong to financial intermediation which require skilled labour in most cases. As export base for neighbouring countries, with a mean of 3.24 is also significant. Turkey is located between Europe and the Middle East and Caucasus. Therefore several foreign investors consider Turkey as an export base for these countries or regions. The availability of industrial infrastructure has a mean of 3.12. With a mean score of 2.78 , gaining access to raw materials is at the bottom of the list. Interestingly, gaining access to raw materials does not play an important role for foreign investors. Turkey is not rich in petrol, iron or electricity or such kinds of resources, therefore foreign investors do not prefer to choose Turkey just in order to gain access to raw materials.

Table 5 supports the idea that foreign investors welcome long-term strategy of the governments and the way that policies were applied. Long-term strategy including adjustment and stabilization policies has a mean score of 3.85 .

Turkey experienced foreign exchange shocks during the 1990s and the volatility of exchange started to decrease after 2001. Therefore in Table 5 we see that foreign investors are pleased with foreign exchange

Table 5. Motives for Foreign Direct Investment in Turkey

\begin{tabular}{|c|c|c|c|c|}
\hline $\begin{array}{l}\text { Economic } \\
\text { Indicators and } \\
\text { Economic } \\
\text { Environment }\end{array}$ & $\begin{array}{l}\text { Number of } \\
\text { Responses }\end{array}$ & Mod & Mean & $\begin{array}{c}\text { Standard } \\
\text { Deviation }\end{array}$ \\
\hline $\begin{array}{l}\text { Long-term } \\
\text { strategy } \\
\text { (adjustment } \\
\text { and Stabilization }\end{array}$ & 52 & 4 & 3.85 & 1.017 \\
\hline $\begin{array}{l}\text { Foreign exchange } \\
\text { policy }\end{array}$ & 47 & 4 & 3.34 & 1.069 \\
\hline Trade regulations & 49 & 3 & 3.1 & 0.984 \\
\hline $\begin{array}{l}\text { Investment } \\
\text { incentives }\end{array}$ & 50 & 2 & 2.98 & 1 \\
\hline $\begin{array}{l}\text { Investment } \\
\text { Promotion }\end{array}$ & 50 & 2 & 2.88 & 1.172 \\
\hline $\begin{array}{l}\text { Investment } \\
\text { facilitation }\end{array}$ & 49 & 2 & 2.86 & 1.19 \\
\hline FDI track record & 46 & 2 & 2.7 & 0.94 \\
\hline
\end{tabular}


policies of the government. Foreign exchange policy has a mean of 3.34. The trade regulations indicator has a mean of 3.10 .

The results of the questionnaire survey in this section indicate that executives of the MNCs operating in Turkey find that investment incentives, investment promotion, FDI track record and investment facilitation are not prior motives for their company to invest in Turkey. In the survey, investment incentives with a score 2.98 , investment facilitation with a mean score of 2.86 and FDI track record with a mean of 2.7 are at the bottom of the list. Investment promotion has a mean score of 2.88 which indicates that Turkey would need to engage in a concerted and focused marketing effort to advertise itself as an attractive investment location abroad. However, Turkey was unable to succeed in establishing a promotion agency until recently and the agency does not have a strong and clear mandate, setup and budget.

Developing a long-term FDI promotion strategy is crucial for several reasons; first, prospective investors, even the largest firms, do not systematically search the world for opportunities. Information is imperfect and risk perceptions may not conform wholly to reality.

The search for opportunities is a bureaucratic process whose initiation and direction may be swayed by many factors, some of which are not purely objective. Many emerging economies such as Malaysia, Poland, the Czech Republic, Hungary, Ireland, and Singapore have active IPA. The IPAs of these countries build techniques to include advertising in general and specialized media; participate in investment exhibitions; facilitate investment missions from source countries; and conduct general information seminars on investment opportunities. Some IPAs go further and use the techniques including direct mail campaigns, industry or sector-specific investment missions or informational seminars, and one-on-one, face-to-face meetings with selected potential investors.

\subsection{The role of institutional variables}

In Turkey for foreign investors, political and macroeconomic instability are seen as the most significant facts that hinder higher inflows of FDI. Stability is a crucial factor when it comes to FDI because it is a way that investors measure the security of their investment and want to see prior to establishing their investment in a host country. It indicates the likelihood that the government in power will be destabilized in unconstitutional way or by violent means. Where investors are uncertain about a country's political and economic stability they adopt a "wait and see" attitude.
Table 6. Barriers to Foreign Direct Investment in Turkey

\begin{tabular}{|c|c|c|c|c|}
\hline (General) & $\begin{array}{l}\text { Number of } \\
\text { Responses }\end{array}$ & Mod & Mean & $\begin{array}{l}\text { Standard } \\
\text { Deviation }\end{array}$ \\
\hline $\begin{array}{l}\text { Political } \\
\text { instability }\end{array}$ & 52 & 5 & 4.37 & 0.817 \\
\hline $\begin{array}{l}\text { Macroeconomic } \\
\text { instability }\end{array}$ & 52 & 5 & 4.35 & 0.738 \\
\hline $\begin{array}{l}\text { Exchange rate } \\
\text { risks }\end{array}$ & 49 & 4 & 3.92 & 1.017 \\
\hline Inflation & 47 & 4 & 3.89 & 0.759 \\
\hline $\begin{array}{l}\text { Insufficient } \\
\text { development of } \\
\text { financial markets }\end{array}$ & 49 & 3 & 3.22 & 1.066 \\
\hline $\begin{array}{l}\text { Slow progress of } \\
\text { privatization prog. }\end{array}$ & 48 & 3 & 3.02 & 1.101 \\
\hline $\begin{array}{l}\text { Possible obstacles } \\
\text { against }\end{array}$ & & & & \\
\hline $\begin{array}{l}\text { EU membership } \\
\text { process }\end{array}$ & 47 & 2 & 2.89 & 1.088 \\
\hline $\begin{array}{l}\text { Competition } \\
\text { with Central and } \\
\text { East European } \\
\text { Countries }\end{array}$ & 48 & 3 & 2.88 & 1.044 \\
\hline
\end{tabular}

In the survey (Table 6), political instability has a mean of 4.37 and macroeconomic instability has a mean of 4.35. In Turkey, some link political stability with a single-party government rather than with coalition parties ruling the country. However, indicators of political stability are government effectiveness, regulatory quality, and the rule of law. Most investors, when creating a business plan or project proposal, want to be able to estimate costs, competition, regulations, and potential returns.

Economic stability can be captured in macro-economic indicators, such as inflation and growth. It can be argued that only if the country can provide a politically and economically more stable and open environment, can more specific efforts, targeted at improving the investment environment directly, be effective.

High mean scores of exchange rate risk and inflation reflect how respondents consider the 2001-2006 period when answering the survey. If the survey had been applied five years earlier the mean scores would be much higher. However, the exchange risk and risk of inflation with mean scores of 3.92 and 3.89 are welcome as deterrent indicators for investors. Insufficient development of financial markets has a 3.22 mean score. Progress in establishing financial infrastructure and capital markets is important for 
foreign investors because it facilitates access to local capital markets. The better developed markets encourage business to set up operations, as they can access complementary local finance more easily, and face lower transaction costs for local financial services such as the payment system. However, foreign investors may substitute locally raised capital for capital raised on international capital markets, which would lead to a reduction of recorded FDI inflow. Nonetheless, the received consensus is that the former effect dominates over the latter.

Although in many studies the positive effect of privatization on FDI is emphasized, interestingly, the slow progress of privatization programs does not have a priority as an obstacle of higher FDI inflow with a mean score of 3.02 .

Privatization is a signal to multinational investors that a country is ready to foster a competitive market economy. FDI can also be very useful to a nation's privatization process by bringing in additional management expertise and marketing channels. Given that, Turkey needs significant FDI to enhance its infrastructure and to achieve its privatization goals, it needs a good environment for privatization and private participation in infrastructure. It also needs to privatize to attract even more $\mathrm{FDI}^{13}$.

Also, possible obstacles against EU membership do not have a priority as an obstacle to higher FDI inflow with a mean score.

Interestingly, respondents do not identify Central and East European countries as primary competitors of Turkey. However, during the FIAS field mission in 2000, more than 50 foreign and domestic firms interviewed identified Hungary, Poland, and the Czech Republic as primary competitors of Turkey for FDI attraction. This finding is also supported in the study of $\mathrm{H}$. Loewendahl and E. Loewendahl (2001).

Table 7 demonstrates significant results regarding institutional variables. Anti-competitive practices by the government (with a mean of 3.98), consistency and predictability of officials' interpretations of regulations (with a mean of 3.92), unstable and unreliable, non-transparent legal and regulatory framework (with a mean of 3.84) problems with recognition of patent rights (with a mean of 3.81) and corruption (with a mean of 3.80) are significant facts hindering the higher level of FDI inflows for foreign investors.

Beyond the establishment of markets as basic institution for the exchange of goods and services, regulatory institutions such as a competition policy are required.
Table 7. Barriers to Foreign Direct Investment in Turkey

\begin{tabular}{lcccc}
\hline $\begin{array}{l}\text { Institutions, } \\
\text { Administrative } \\
\text { Barriers }\end{array}$ & $\begin{array}{c}\text { Number of } \\
\text { Responses }\end{array}$ & Mod & Mean & $\begin{array}{c}\text { Standard } \\
\text { Deviation }\end{array}$ \\
\hline $\begin{array}{l}\text { Anti-competitive } \\
\text { practices by } \\
\text { government }\end{array}$ & 47 & 4 & 3.98 & 0.872 \\
\hline $\begin{array}{l}\text { Consistency/ } \\
\text { predictability } \\
\text { of officials' } \\
\text { interpretations } \\
\text { of regulations }\end{array}$ & 51 & 4 & 3.92 & 0.744 \\
\hline $\begin{array}{l}\text { Unstable and } \\
\text { unreliable, non- } \\
\text { transparent legal } \\
\text { and regulatory } \\
\text { framework }\end{array}$ & & & & \\
\hline $\begin{array}{l}\text { Problems with } \\
\text { recognition of } \\
\text { patent rights }\end{array}$ & 50 & 5 & 3.84 & 1.131 \\
\hline $\begin{array}{l}\text { Corruption } \\
\text { Start up }\end{array}$ & 48 & 4 & 3.81 & 0.915 \\
\hline procedures & 49 & 3 & 3.76 & 0.99 \\
\hline $\begin{array}{l}\text { Tog many } \\
4\end{array}$ & & & & \\
\hline
\end{tabular}

Too many days

to resolve a

commercial

dispute in the

$\begin{array}{lllll}\text { country's courts } & 46 & 3 & 3.59 & 0.884\end{array}$

Lack of

enforcement

of laws and

Contracts to

compete

$\begin{array}{lllll}\text { effectively } & 50 & 4 & 3.54 & 1.014\end{array}$

Complex, slow

and expensive

property

registration

\begin{tabular}{lllll} 
process & 48 & 3 & 3.54 & 0.824 \\
\hline
\end{tabular}

Delays in the

$\begin{array}{lllll}\text { courts } & 48 & 3 & 3.5 & 0.968\end{array}$

While liberalization has been rapid throughout the developing countries including Turkey, the process of designing and implementing competition policy has been far more complex ${ }^{14}$.

Governments in the less reformed countries continue to protect the markets of their local firms, even at the sub-national level. Studies, especially those focusing on transition economies reveal that only successful im- 
plementation has a strong positive relationship with the economy-wide intensity of competition, whereas the mere existence of rules does not.

The rule of law refers to the enforceability of contracts, something on which foreign investors place great importance. Investors want to know that their rights and their business will be protected when operating abroad. Corruption diminishes the rule of law, most simply because some businesses do not operate within the law and this reduces fair competition.

Unstable and unreliable, a non-transparent legal and regulatory framework with a mean of 3.84 is regarded as one of the most important deterrent factors by respondents. This is because an efficient legal infrastructure reduces institutional uncertainties for foreign investors, facilitates the establishment and enforcement of contracts and in various other ways reduces the transaction costs of doing business in an economy. Turkey has fallen behind many other developing countries in effective liberalization of its legal framework, and in its enforcement practices to reap the benefits of the rapid globalization that is transforming international economic relationships. Poor implementation of existing legislation is one the main problems in Turkey. Missing implementing rules and administrative guidelines, inconsistent application of laws, incompetent bureaucrats in charge, and lack of judicial enforcement are the issues mentioned most frequently by foreign investors in interviews.

From the perspective of foreign investors, legislative reform in Turkey does not appear to be sufficiently reliable. Adopted laws are often not implemented on time.

One of the executives replied to the question about the newly enacted laws: "Are you satisfied with the progress in the judicial system? By giving an answer, governments may carry on enacting laws; however, we are suspicious about the way they are interpreted". Another point frequently raised by investors is a lack of confidence in the impartiality and quality of the commercial courts. Plus, most of the executives mentioned that unstable, non-transparent legal and regulatory framework make the Turkish business environment difficult to operate. Some argued that recently enacted laws about the recognition of patent rights are not applied with sensitivity.

Corruption is another issue raised by investors. While the recent government efforts to curb corruption deserve much praise, investors suggested that they do not trust in the impartiality of administrators in critical cases, especially in customs administration and municipal level procedures such as site development. Cor- ruption is marked in the Transparency International's year 2000; according to corruption perception index Turkey ranks $50^{\text {th }}$ among 90 nations listed (Transparency International 2006).

Most of the executives I interviewed mentioned that corruption is a deterrent factor for foreign firms. I asked whether corruption may make things easier in the first steps (the short term) of the investment process. All the answers emphasized that large corporations pay special attention to the institutional organization of the corporations. An institutionalized corporation pays special attention to certainty when operating in another country. Corruption makes things uncertain in a business environment which in the end may have negative effect on all firms operating in the long run.

The weakness of the judicial system and enforcement of contracts and the recognition of property rights create a feeling of insecurity and arbitrariness. Under such circumstances, the long-term commitment of substantial investment funds seems risky if plans are challenged or overturned from day to day, or whenever an official is replaced. The weakness of the judicial system causes the increasing and unrestrained power of such officials. Plus, in countries in which the enforcement mechanisms are weak, the share of informal economy is large, in parallel. In other words, compliance with the formal institutions is too costly and the government does not have the power to effectively enforce its costly rules in these countries. It is important to improve the enforcement of dispute resolution and "conflict of interest" legislation.

However, in Turkey the executives that I interviewed emphasized that some of the laws in Turkey are ambiguous and therefore difficult to enforce. The rule of law is perceived as weak by foreign investors. This problem can be improved by creating an independent dispute resolution mechanism or by improving the legitimacy of those responsible for regulating legal disputes and contracts.

Not only are the administrative procedures time-consuming; enforcement procedures for commercial cases at the courts take much longer than in many other countries.

The protection of intellectual property rights is particularly important for producers with a high rate of innovation like computer software developers or pharmaceuticals, as well as producers of products with well-known trademarks like some beverages, clothes, or automobiles. As globalization has taken hold, good IPR protection is becoming more and more important to attract world-class technology and the export-oriented plants that have to use it. 
As in other dimensions of the business environment in Turkey, the major problems in IPR protection are caused not so much by inadequate laws as by a lack of effective enforcement. Internationally known brand names and trademarks are increasingly subject to illegal exploitation and pirating. Since 1992, the US Treasury has listed Turkey on its Priority Watch List, under its Special 301 provision for continuous violation of intellectual property rights (FIAS 2001a, b).

Whole legal framework for intellectual property rights is relatively new in Turkey, and much effort has been spent on fulfilling obligations stemming from the membership of the WTO and the accession to the EU. In the survey, administrative barriers such as complex, slow and expensive property registration process and too many days to resolve a commercial dispute in the country's courts have 3.59 and 3.50 mean scores. The mean scores are significant although these indicators stay behind the several institutional variables in the list.

\subsection{The Quality and Integrity of Public Services}

The overall quality and efficiency of services gives an idea about the legislation, infrastructure, and the sensitivity towards protecting property rights. As they find these services attractive, they inform of the quality of the services to the foreign investors outside the country.

The overall quality and efficiency of services delivered by the following public agencies or services ( 1 very bad to 5 very good) are presented in Table 8 .

Table 8. Functioning of Institutions and Public Services

\begin{tabular}{|c|c|c|c|c|}
\hline Indicators & $\begin{array}{l}\text { Number of } \\
\text { Responses }\end{array}$ & Mod & Mean & $\begin{array}{l}\text { Standard } \\
\text { Deviation }\end{array}$ \\
\hline Property rights & 49 & 3 & 3.14 & 0.89 \\
\hline $\begin{array}{l}\text { Labour } \\
\text { regulations }\end{array}$ & 49 & 3 & 3.04 & 1.06 \\
\hline $\begin{array}{l}\text { Business } \\
\text { licensing }\end{array}$ & 47 & 3 & 3.02 & 0.737 \\
\hline $\begin{array}{l}\text { Tax regulations/ } \\
\text { administration }\end{array}$ & 49 & 3 & 2.69 & 0.713 \\
\hline
\end{tabular}

When the quality and integrity of public services are considered, it can be argued that indicators such as property rights, labour regulations and business licensing have moderate mean scores except for the quality of tax regulations and administration. Property rights has a mean score of 3.14; labor regulations 3.04, and business licensing - 3.02. Executives, dur- ing the interviews, mentioned that tax regulations were complex, inefficient and hence, a deterring factor for FDI inflows.

Table 9 demonstrates that whereas indicators belonging to infrastructure have high mean scores, administrative and legislative issues have relatively low scores. Communication service is at the top of the list with a mean score of 3.87. Electric power has a mean score of 3.51, while transportation service has a score of 3.40 and the quality of roads has a mean score of 3.22. On the other hand, the quality of the functioning of government comes after the indicators of infrastructure with a mean score of 3.16. The score of 2.86 for the parliament and 2.65 for the judicial system reveal that foreign investors are suspicious about the quality of legislative and administrative functioning.

Table 9. Infrastructure and Legislation (1 very bad; 5 very good)

\begin{tabular}{lcccc}
\hline Indicators & $\begin{array}{c}\text { Number of } \\
\text { Responses }\end{array}$ & Mod & Mean & $\begin{array}{c}\text { Standard } \\
\text { Deviation }\end{array}$ \\
\hline $\begin{array}{l}\text { Communication } \\
\text { service }\end{array}$ & 52 & 4 & 3.87 & 0.793 \\
\hline $\begin{array}{l}\text { The electric } \\
\text { power }\end{array}$ & 51 & 4 & 3.51 & 1.189 \\
\hline $\begin{array}{l}\text { Transportation } \\
\text { service }\end{array}$ & 52 & 3 & 3.4 & 0.774 \\
\hline $\begin{array}{l}\text { Roads } \\
\text { Functioning of } \\
\text { government }\end{array}$ & 50 & 3 & 3.22 & 1.016 \\
\hline The parliament & 50 & 3 & 2.8 & 0.857 \\
\hline Judicial system & 52 & 3 & 2.65 & 0.861 \\
\hline
\end{tabular}

As seen from the survey, the functioning of the judicial system and the predictability of rules and regulations are perceived as significant by respondents. In order to get specific results, I asked questions regarding the year 2001 and the year 2006, in order to see whether any progress had taken place in five years on these specific issues. In order to get specific results, I offered specific statements and asked if the respondents agreed with the statements or not.

The responses to the statement reveal that there was progress in obtaining information on the laws and regulations affecting respondents' firms (Table 10). Considering the year 2001, 15 respondents stated that receiving information on the laws and regulations was easy to obtain, whereas regarding the year 2006 the number of respondents agreeing with the statement reached 37. Twelve respondents disagreed with the 
Table 10. Statement 1: "In general, information on the laws and regulations affecting my firm is easy to obtain"

\begin{tabular}{cccccccc}
\hline Years & \multicolumn{3}{c}{2001} & & \multicolumn{2}{c}{2006} \\
\hline Number of firms & Agree & Disagree & No Idea & Agree & Disagree & No Idea \\
\hline 51 & 15 & 12 & 24 & 37 & 4 & 10 \\
\hline
\end{tabular}

Table 11. Statement 2: "In general, interpretations of regulations affecting my firm are consistent and predictable"

\begin{tabular}{ccccccc}
\hline Years & \multicolumn{3}{c}{2001} & & \multicolumn{2}{c}{2006} \\
\hline Number of firms & Agree & Disagree & No Idea & Agree & Disagree & No Idea \\
\hline 51 & 8 & 27 & 16 & 22 & 17 & 12 \\
\hline
\end{tabular}

statement for the year 2001, whereas this number decreased to four for 2006. The number of indifferent respondents decreased from 24 for 2001, to 10 for 2006.

Especially during the interviews, one of the important tasks that executives faced was the interpretations of regulations. Most of the executives stated that, although significant changes took place in many areas such as the legislative and judicial system, and different interpretations of laws affect their operations negatively (Table 11). However, the table demonstrates that over the years, the number of respondents considering the interpretations of regulations as predictable and consistent increase significantly. Regarding 2001, eight respondents believed in the consistency and predictability of regulations whereas, by 2006 , the number increased to 22 .

While the share of respondents decreased, the number of indifferent respondents, only slightly changed.

These results suggest that for the respondents, access to the information ofn laws and regulations, and the predictability and consistency of the regulations regarding their business improved during five years.

However, according to respondents, while the predictability and consistency of regulations related to their business increased, in general, they are skeptical about

Table 12. Changes in economic and financial policies are (1:highly unpredictable; 5 : highly predictable)

\begin{tabular}{lll}
\hline Indicators & $\begin{array}{l}\text { Number of Mod Mean } \\
\text { Responses }\end{array}$ & $\begin{array}{c}\text { Standard } \\
\text { Deviation }\end{array}$ \\
\hline
\end{tabular}

\section{Changes in}

rules, laws and

\begin{tabular}{lllll} 
regulations & 51 & 3 & 2.37 & 0.999 \\
\hline
\end{tabular}

Changes in economic and

financial policies

$\begin{array}{llll}50 & 3 & 2.22 & 0.996\end{array}$

the certainty and predictability of the general policy changes in the country (Table 12). The lowest mean scores in the survey are related to the predictability of changes in rules, laws and regulations (2.37 mean score) and changes in economic and financial policies (2.22). Law-making procedures often lack participation of the people subject to it. Business organizations in Turkey complain that they are often not consulted when important legislation for the business environment is being drafted; this again indicates that most officials do not see investors as a constituency which they should heed. The business community feels left out in the democratic process of discussing changes in the legislation.

\section{Conclusions}

The findings presented in this paper, when incorporated with the existing works on FDI, provide an explanation of the distribution of foreign direct investment across countries. The empirical results point to the importance of political and economic institutions for foreign direct investment.

In this paper, my results point out that the effect of macroeconomic indicators such as market size, growth rate, GDP per capita on FDI is positive. In addition, what this study suggests is that institutional variables such as low level of corruption, government stability, enforcement of contract law, functioning of judicial system, transparent, legal and regulatory framework, political and economic stability, intellectual property rights, efficiency of justice and prudential standards have also significant impact on FDI in Turkey.

These results make a real contribution to the empirical literature by validating the role of a large set of institutional variables on foreign direct investment flows and they are encouraging in the sense that efforts towards raising the quality of institutions may help Turkey to receive more FDI, hence help the country to 
enjoy higher values of GDP per capita. The results of the study reveal that the nature of the interaction between MNCs and each country is the result of a more complex set of factors than only market size or market-related variables orientation. It takes place within the host country's unique economic, social, and legal structures; it involves institutions.

As a rule, legal infrastructures, including legal system development and enforcement, are generally weak in most developing countries. Bribery and corruption are obviously more invasive in emerging markets than in advanced economies. The roles of law and judicial systems differ among countries. The gap between the law on the books and the law in practice can be vast. Legal standards tend to be ideals, not necessarily achievable.

A stable, reliable, business climate will lower costs, thereby encouraging FDI. Avoiding problems with regulatory, bureaucratic and judicial hurdles, property rights, enforceable contracts, performance and content requirements, or bribe payments will be seen as positive because they reduce risk and uncertainty.

Recently, Turkey has made considerable progress in modernizing its business legislation. In the first half of the 1980s there were major reforms, and a second wave that began in the mid-1990s is still underway. While there are some gaps in the body of laws and regulations, poor implementation of existing legislation is the main problem. Missing implementing rules and administrative guidelines, inconsistent application of laws, incompetent bureaucrats in charge, and lack of judicial enforcement are the main problems.

In order to increase the quality of institutions in order to enjoy high economic growth rates and receive high levels of FDI inflows the state should adopt several policies such as introduction of independent regulatory agencies in various fields such as competition, banking, and telecommunications; adoption of modern legislation to protect industrial property rights; invitation of all relevant business association to comment on draft legislation.

In conclusion, the ability of countries to benefit from investment activities is influenced by active policies. By providing the appropriate legal and institutional environment, host country governments can create conditions that will not only attract foreign investors, but also encourage local firms to expand their investment or to establish new operations.

\section{Endnotes}

${ }^{1}$ I would like to thank for the support received from the European Science Foundation (ESF) 'Globalizing European Economic History Network'. I was fortunate to have the opportunity to present the article in progress at Tartu University and the seventh European Historical Economics Society conference at Lund University; I am pleased to acknowledge the helpful comments made by the participants of those meetings. I am indebted to Professor Asim Erdilek, Case Western Reserve University, and Professor Murat Cokgezen, Marmara University, for their valuable comments on an earlier draft of this paper.

2 Recently, the coalition government and succeeding AKP government paid special attention to inward FDI and approved legislative revisions concerning FDI. A new FDI encouragement law was enacted in 2003, the complicated entrance procedures were simplified, and for the first time, the state accepted to work in accordance with non-governmental organizations and the private sector in order to improve the investment environment for foreign investor. Plus, in support of these efforts, Foreign Investment Advisory Service of the World Bank has been asked to analyze the business climate in Turkey and prepare this report which indicates the government's willingness to attract more FDI inflows to Turkey.

3 The index captures the influence on FDI of factors other than market size, assuming that, other things being equal, size is the "base line" for attracting investment. These other factors can be diverse, ranging from the business climate, economic and political stability, the presence of natural resources, infrastructure, skills and technologies, to opportunities for participating in privatization or the effectiveness of FDI promotion.

4 The indices exclude tax havens, which for tax rather than productive reasons tend to have massive FDI inflows in relation to their economic size.

${ }^{5}$ Values (GDP per capita, GDP growth, Share of Exports in GDP, Average Number of Telephone Lines per 1,000 inhabitants and Mobile telephones per 1,000 inhabitants, commercial energy use per capita, the share of R\&D spending in GDP, the share of tertiary students in the population, country risk, the World market share in exports of natural sources, the World market share of exports of services and the share of world FDI inward stock) are scores between zero, for the lowest scoring country, to one, for the highest and of 12 variables, no weights are attached in the absence of a priori reasons to select particular weights.

${ }^{6}$ UNCTAD, World Investment Report, 2006a: 6. Also see Lopez-Claros et al. (2006).

7 According to one of the oldest definitions of Foreign Direct Investment, by Kindleberger, FDI is referred to as long-term capital flow and differs from portfolio investment by taking place in kind, through the exchange of property (patents, technology or machinery) and by acquiring control of a company. Kindleberger 1969, 2), for further discussions on the definition of FDI see (OECD 1996), Lipsey 2001).

${ }^{8}$ Hymer wrote a $\mathrm{PhD}$ dissertation "The International Operations of National Firms: A Study of Direct Foreign Investment", published posthumously in 1976. In his dissertation, Hymer asserted that FDI took place not because of a higher marginal rate of return in perfect capital markets as the neoclassical economists assume but because the corporation making the investment possessed some special skill or techniques 
not available to local entrepreneurs that it could exploit only through direct ownership.

${ }^{9}$ Economic institutions matter for economic growth because they shape the incentives of the key economic actors in society; in particular, they influence investments in physical and human capital and technology, and the organization of production. Political institutions help to regulate the limits of political power and determine how political power changes hands (constitution, electoral rules, the number of veto players, etc).

${ }^{10}$ However, some should pay attention to the facts that results can be considered to be subjective and more important, they measure the perceptions of institutional quality rather than its actual quality. Therefore, in this paper, what I am concerned about is not the actual institutional quality, but its perceptions on the quality of institutions.

${ }^{11}$ In the FIAS field survey, conducted through YASED (International Investors Association) to 56 foreign investors in Turkey, more than 50 percent of existing investors have invested in Turkey for its large domestic market, skilled and cost-effective labour (FIAS 2001).

12 IMD, World Competitiveness Yearbook. 2000. Other comparisons in this document show other dimensions of competitive nature of the Turkish work force.

13 A FIAS study on "Facilitating Foreign Participation in Privatization," for a sample of 36 countries implementing privatization programs concluded that every dollar of privatization revenues attracted on average an additional 88 cents in FDI. See: Megyery and Sader 1996.

14 See: Hare et al. (1999: 1-30).

\section{References}

Acemoglu, D.; Johnson, S.; Robinson, J. A. 2005. Institutions as the fundamental cause of long-run growth, in Aghion, P. and Durlauf, S. N. (Eds.). Handbook of Economic Growth, Amsterdam: North-Holland.

Acemoglu, D.; Johnson, S.; Robinson, J. A. 2002. The rise of Europe: Atlantic trade, institutional change and economic growth. MIT, Sloan School of Management. Working paper No. 4269-02.

Ashkin, D. 1972. Evolution of private foreign investment climate in Turkey. Florida State University, D. B. A.

Bulutoglu, K. 1970. 100 soruda Türkiye'de yabancı sermaye [Foreign Direct Investment in Turkey: 100 questions]. İstanbul: Gercek Publications.

Coase, R. H. 1960. The problem of social cost, Journal of Law and Economics 3(October): 1-44.

Degutis, M.; Tvaronavičienè, M. 2006. Factor analysis of Lithuanian and Estonian inward direct investment, Verslas: teorija ir praktika [Business: Theory and Practice] 7(3): $150-158$.

Dumludag, D.; Sukruoglu, D. 2007. The impact of macroeconomic and institutional variables on foreign direct investment flows in emerging markets, Marmara Üniversitesi IIBF Dergisi 23(2): 133-166.

Dumludag, D. 2007. Foreign direct investment in developing economies and Turkey: the Role of Institutions: PhD Dissertation. Istanbul: Bogazici University.
Dunning, J. H. 1970. Studies in international investment. London: George Allen \& Unwin, Ltd., Economica 38(149): $1-27$.

Erden, D. 1996. A survey of foreign direct investment firms in Turkey. Istanbul: Bogaziçi University.

Erdilek, A. 1982. Direct foreign investment in Turkish manufacturing. Tubingen: Mohr Siebeck GmbH \& Company KG.

Erdilek, A. 1986. Turkey's new open door policy of direct foreign investment: A critical analysis of problems and prospects, METU Studies in Development 13(1/2):171-191.

Esiner, E. H. 1966. Türkiye'de Sinai Yatırımlarda Yabancı Sermaye [Foreign Capital in Industrial Investments in Turkey], Istanbul.

FIAS (Foreign Investment Advisory Service). 2001a. A Diagnostic Study of the Direct Foreign Investment Environment in Turkey. Washington: The World Bank.

FIAS (Foreign Investment Advisory Service). 2001b. Turkey's Administrative Barriers to Investment. Washington: The World Bank.

Gastanaga, V.; Nugent, J.; Pashamova, B. 1998. Host country reforms and FDI inflows: How much difference do they make? World Development 26(7): 1299-1314.

Ginevičius, R.; Tvaronavičienè, M. 2003. Čo privádza priame zahraničné Investicie do pobaltských krajin? Pripad Litvy, Lotyšska a Estónska [What Drives Foreign Direct Investments into Baltic Countries? The Case of Lithuania, Latvia and Estonia], Ekonomický Časopis [Journal of Economics] 51(8): 963-981.

Ginevičius, R.; Tvaronavičienè, M. 2004. Risk of globalization: Case study of Lithuanian economy, Ekonomický Časopis [Journal of Economics] 2: 212-231.

Habib, M.; Zurawicki, L. 2001. Corruption and foreign direct investment, Journal of International Business Studies 33(2): 290-307.

Hall, R. E.; Jones, C. I. 1999. Why do some countries produce so much more output per worker than others? Quarterly Journal of Economics 114(1): 83-116.

Hare, P. G.; Batt, J.; Cave, M.; Estrin, S. 1999. Introduction, in Hare, P.; Batt, J.; Estrin, S. (Eds.). Reconstituting the Market, The Political Economy of Microeconomic Transformation. Harwood Academic: Amsterdam.

Hymer, S. 1976. The theory of international operations. Cambridge, MA: MIT press.

IMD. 2000. World Competitiveness Yearbook. Available from Internet: <http://www.imd.ch/research/publications/ wcy/index.cfm $>$.

Jensen, N. M. 2006. Nation States and the multinational corporation, a Political Economy of Foreign Direct Investment. New Jersey: Princeton University Press.

Karluk, R. 1982. Turkiye'de Yabancı Sermaye Yatırımları [Foreign direct investment in Turkey], Istanbul: İstanbul Ticaret Odas1 [Istanbul Chamber of Commerce].

Kindleberger, C. 1969. American investment abroad. New Haven: Yale University Press. 
Knack, S.; Keefer, P. 1995. Institutions and economic performance: cross-country tests using alternative institutional measures, Economics and Politics 7(3): 207-227.

Knickerbocker, F.T. 1973. Oligopolistic reaction and multinational enterprise. Boston: Harvard University.

Li, Q.; Resnick, A. 2003. Reversal of fortunes: democratic institutions and foreign direct investment inflows to developing countries, International Organization 57(1): 175-211.

Lipsey, R. E. 2001. Foreign direct investment and theoperations of multinational firms: Concepts, history and data. Available from Internet: <http://www.nber.org/papers/ w8665.pdf $>$.

Loewendahl, H.; Loewendahl, E. E. 2001. Turkey's performance in attracting foreign direct investment implications of EU enlargement. Available from Internet: $<$ http://aei.pitt. edu/1860/01/ENEPRI_WP08.pdf $>$

Lopez-Claros, A.; Porter, M. E.; Sala-i-Martin, X.; Schwab, K. 2006. The global competitiveness report 2006-2007. Hampshire, UK: Palgrave Macmillan.

Markusen, J. R. 1995. The boundaries of multinational enterprises and the theory of international trade, Journal of Economic Perspectives 9(2):169-189.

Mauro, P. 1995. Corruption and growth, Quarterly Journal of Economics 110(3): 681-712.

Mauro, P. 1997. The effects of corruption on growth, investment and government expenditures: a country analysis, in Eliot, K. S. (Ed.). Corruption and Global Economy. Washington, D. C.: Institute for International Economics.

Megyery, K.; Sader, F. 1996. Facilitating foreign participation in privatization. Washington D.C.: IFC.

Michalet, C. A. 1997. Strategies of multinationals and competition for foreign direct investment. Washington: The World Bank. 46 p. ISBN 0-8213-4161-8.

Noorbakhsh, F.; Paloni, A.; Youssef, A. 2001. Human capital and FDI inflows to developing countries: New empirical evidence, World Development 29(9): 1593-1610.

North, D. C. 1990. Institutions, institutional change, and economic performance. New York: Cambridge University Press.

Nunnenkamp, P.; Spatz, J. 2002. Determinants of FDI in developing countries: Has globalization changed the rules of the game? Transnational Corporations 11(2): 1-34.

OECD (Organization for Economic Co-operation and Development) 1996. OECD benchmark definition of foreign direct investment. Available from Internet: <http://www. oecd.org/dataoecd/10/16/2090148.pdf>.

Oksay, K. 1967. Turkiye'de Yabancı Sermaye Yatırım Kllavuzu [A guide for foreign direct investment in Turkey]. Istanbul: Dogan Kardes Publicatons.

Oxley, J. E. 1999. Institutional environment and the mechanisms of governance: The impact of intellectual property protection on the structure of inter-firm alliances, Journal of Economic Behavior and Organization 38(3): 283-309.

Şahin, M. 1975. Turkiye'de Yabancı Sermaye Yatırımları [Foreign direct investment in Turkey]. Ankara: Ekonomik ve Sosyal Yayınları.

Selik, N. 1961. Turkiye'de Yabancı Ozel Sermaye [Private foreign direct investment in Turkey 1923-1960]. Ankara: Siyasal Bilgiler Fakultesi.

Smarzynska, B. K. 1999. Composition of foreign direct investment and protection of intellectual property rights in transition economies. CEPR Working Paper No. 2228. Center for Economic Policy Research: London.

Tatoğlu, E. 1998. An analysis of the dimensions of Western foreign direct investment in Turkey. Leeds, U.K.: University of Leeds.

TI (Transparency International). 2006. Transparency International Rankings. Available from Internet: $<$ http://www. transparency.org>.

Tuncer, B. 1968. Turkiye'de Yabancı Sermaye Sorunu [Foreign direct investment problem in Turkey]. Ankara: Siyasal Bilgiler Fakültesi Yayınları.

Tvaronavičienè, M.; Grybaite, V. 2007. Impact of FDI on Lithuanian economy: insight into development of main economic activities, Journal of Business Economics and Management 8(4): 285-290.

Tvaronavičienè, M.; Degutis, M. 2007. If approach to innovations differs in locally and foreign owned firms: case of Lithuania, Journal of Business Economics and Management 8(3): 195-203.

Tvaronavičienė, M.; Grybaitė, V.; Korsakienė, R. 2008. Foreign capital destinations: Baltic states versus India, Journal of Business Economics and Management 9(3): 227-235.

UNCTAD (United Nations Conference on Trade and Development). 2006a. World Investment Report, FDI from Developing and Transitional Economies: Implications for Development. Available from Internet: $<$ http://www.unctad. org/en/docs/wir2006_en.pdf>.

UNCTAD (United Nations Conference on Trade and Development). 2006b. Handbook of Statistics UNCTAD. Available from Internet: $<$ http://www.unctad.org/Templates/Page. asp?intItemID=1584\&lang=1>.

Uras, G. 1979. Turkiye'de Yabancı Sermaye Yatırımları [Foreign direct investment in Turkey]. Istanbul: Formul Publ.

Vernon, R. 1966. International investment and international trade in the product cycle, Quarterly Journal of Economics 80(2): 190-207.

Wei, S. 1997. Why is corruption so much more taxing than tax? Arbitrariness Kills. NBER Working Paper No. W6255.

Wheeler, D.; Mody, A. 1992. International investment location decisions: The Case of U.S. Firms, Journal of International Economics 33: 57-76. 